\title{
Life history, growth and production of Neomysis integer in the Westerschelde estuary (SW Netherlands)
}

\author{
Jan Mees, Zekeria Abdulkerim, Olivier Hamerlynck \\ Marine Biology Section, Zoology Institute, University of Gent, K. L. Ledeganckstraat 35, B-9000 Gent, Belgium \\ and \\ Centre for Estuarine and Coastal Ecology, Vierstraat 28, 4401 EA Yerseke, The Netherlands
}

\begin{abstract}
The Neomysis integer (Leach, 1814) (Crustacea, Mysidacea) population of the brackish part of the Westerschelde estuary was sampled on a fortnightly basis from November 1990 to December 1991. Density, biomass, population structure and brood size were recorded. The Bhattacharya method was applied to the length-frequency data for the detection and separation of cohorts. Growth is described both by a generalised von Bertalanffy function and by a von Bertalanffy function incorporating seasonal oscillations in growth. Secondary production was estimated for each cohort using 4 approaches. The seasonal pattern in density and biomass showed 3 peaks: a relatively small, yet distinct, peak in early March (30 ind. $\left.\mathrm{m}^{-2}, 60 \mathrm{mg} \mathrm{AFDW} \mathrm{m}^{-2}\right)$ and 2 main peaks in late spring $\left(160 \mathrm{ind} . \mathrm{m}^{-2}\right.$, $\left.225 \mathrm{mg} \mathrm{AFDW} \mathrm{m}^{-2}\right)$ and in summer $\left(140\right.$ ind $\left.\mathrm{m}^{-2}, 125 \mathrm{mg} \mathrm{AFDW} \mathrm{m}^{-2}\right)$. Throughout winter, $N$. integer density remained well below 30 ind. $\mathrm{m}^{-2}$ Three periods of increased reproductive activity and subsequent input of juveniles were found. This suggests that 3 cohorts were produced per year. The overwintering generation lived from autumn until the following spring. The spring generation was born in early spring and lived for about 3 mo, while the summer generation lived from summer until early winter. The 3 cohorts showed marked differences in their biology. The overwintering generation showed seasonal growth oscillations, larger brood size and a larger size at maturity. Individuals belonging to the other 2 cohorts generally grew faster, produced less young per female, and attained maturity at a smaller size. Within each cohort, both sexes exhibited different growth characteristics: females generally lived longer, grew faster and consequently became larger than males. The size-frequency, growth summation and removal summation methods yielded comparable production estimates. The annual production was $0.3 \mathrm{~g} \mathrm{AFDW} \mathrm{m}^{-2} \mathrm{yr}^{-1}$ with an annual $\mathrm{P} / \mathrm{B}$ ratio of 6 . The average cohort $\mathrm{P} / \mathrm{B}$ was 3 . The size-frequency method gave similar results only when applied to the 3 cohorts and to both sexes separately. The spring cohort accounted for almost half of the annual production. Despite the longer life span of the overwintering generation, it generated only a quarter of the annual production. An independent estimate of production using the mortality rate of the different cohorts resulted in values comparable to those obtained by the other methods for the overwintering cohort, while the production of the other 2 cohorts was overestimated.
\end{abstract}

KEY WORDS: Neomysis integer - Mysidacea - Estuary - Westerschelde - Life history - Growth · Production

\section{INTRODUCTION}

Generally the lack of reliable estimates of secondary production due to poorly documented life history data for key species constitutes a major problem in understanding the functioning of aquatic ecosystems. This problem occurs especially in studies of energy flows through food webs in estuaries.
Estuaries are highly productive ecosystems. They are widely recognised as important nurseries for fish and epibenthic crustaceans. Especially the low salinity zone around the typical estuarine turbidity maximum is characterised by high amounts of organic detritus, high densities of zooplankton (Soetaert \& van Rijswijk 1993), epi- and hyperbenthos and both demersal and pelagic fish (Hamerlynck et al. 1993, Mees et al. 1993b). 
The genus Neomysis Czerniavsky has representatives on and around each continent and detailed studies exist on the biology of several species (e.g. Ishikawa \& Oshima 1951, Heubach 1969, Pezzack \& Corey 1979, Toda et al. 1982, Cooper et al. 1992 and references therein). Neomysis integer (Leach, 1814) is one of the most common mysids around the coasts of Europe. It is a hyperbenthic, euryhaline and eurythermic species, typically occurring in high numbers in estuarine, brackish water environments (Tattersall \& Tattersall 1951). It also occurs in oligohaline to freshwater bodies which in recent geological history were connected to the sea (Bremer \& Vijverberg 1982). Tesch (1911) reported the species to be common in and characteristic for low salinity waters in the delta area in the southwest of The Netherlands.

This study, which is part of an integrated study on major food chains in European tidal estuaries, focuses on the estimation of the production of Neomysis integer.

The life history of lacustrine Neomysis integer populations in the Dutch delta was previously studied by Borghouts (1978) and Platenkamp (1983). The biology of $N$. integer in lakes and pools in The Netherlands was studied by Vorstman (1951), Beattie \& de Kruijf (1978) and Bremer \& Vijverberg (1982). Other valuable information is available on populations in a Scottish loch (Mauchline 1971), an Irish lough (Parker \& West 1979) and in the coastal waters of the Baltic (Wiktor 1961, Jansen et al. 1980, Rudstam et al. 1986). Life cycle studies in the Ythan, Scotland (Astthorsson \& Ralph 1984), the Eider-Ring, Germany (Kinne 1955) and the Gironde, France (Sorbe 1981) are the only estuarine studies to date, but these do not give any production estimates of $N$. integer.

Baseline studies on spatial and temporal patterns in the hyperbenthic component of the Westerschelde have been published (Mees \& Hamerlynck 1992, Mees et al. 1993a, b). These studies indicated Neomysis integer as the dominant species in the brackish part of the estuary, both in the main channel and adjacent tidal marshes. The mysid was recorded in salinities ranging from 8 to 25 PSU, but it was never found downstream of Hansweert (Fig. 1). The lacustrine limit of the population lies a few kilometres upstream of the DutchBelgian border (Mees et al. 1993a). Data on the horizontal distribution of the Westerschelde population are described in Mees et al. (1993b). As life history characteristics of a species can vary considerably from one habitat to another, local knowledge of the biology of $N$. integer in the Westerschelde is essential for further use in ecosystem modelling, energy-flow studies and experimental work (e.g. von Oertzen et al. 1988).

Neomysis integer is an omnivorous species. As a predator on zooplankton (e.g. Bremer \& Vijverberg
1982) it can structure zooplankton populations and as a detritivore it can also, to a certain extent, affect the detrital food chain. The species is also an important prey for demersal and pelagic fish and larger epibenthic crustaceans (e.g. Mauchline 1980). In the Westerschelde $N$. integer is known to be a major food source for sand goby Pomatoschistus minutus, Lozano's goby P. lozanoi, common goby P. microps, seabass Dicentrarchus labrax, bib Trisopterus luscus, sea snail Liparis liparis, pipefish Syngnathus rostellatus and the brown shrimp Crangon crangon (A. Cattrijsse \& K. Hostens pers. comm.). Other potential (and commercially important) predators on $N$. integer include sprat Sprattus sprattus, herring Clupea harengus, flounder Pleuronectes flesus, dab Limanda limanda and plaice Pleuronectes platessa (Mauchline 1980), all of which are common in the study area (Hamerlynck et al. 1993). It is therefore believed to be a key species in the ecosystem of the brackish part of the Westerschelde.

\section{MATERIALS AND METHODS}

Study area. The Westerschelde estuary (Fig. 1) is the lower part of the river Schelde. The maritime zone of the tidal system is about $70 \mathrm{~km}$ long from the North Sea (Vlissingen) to the Dutch-Belgian border near Bath. The Westerschelde is the last remaining true estuary of this delta area and is characterised by a marked salinity gradient. The water is completely mixed and the residence time is rather high (about $70 \mathrm{~d}$ or 150 tidal cycles). Consequently, freshwater (average inflow $100 \mathrm{~m}^{3} \mathrm{~s}^{-1}$ ) dilution is gradual and this results in relatively stable salinity zones which are maintained in more or less the same position throughout a tidal cycle. The most important shifts occur in accordance with seasonal variations in the freshwater inflow. The abiotic environment is discussed in Heip (1988) and Van Eck et al. (1991).

Sampling. Samples were taken on a more or less fortnightly basis from 27 November 1990 to 16 December 1991. In December 1990, May 1991 and September 1991 the estuary could only be sampled once (Table 1). Each sampling day 4 stations (OV, SA, BA and LI) were covered (Fig. 1). Sampling was done from the RV 'Luctor'. All samples were taken during daytime when hyperbenthic mysids are known to concentrate near the bottom. The samples were collected with a hyperbenthic sledge (Hamerlynck \& Mees 1991), 1 m wide, consisting of a heavy metal frame equipped with 2 nets, one above the other. The catch in both nets was pooled for this study. The nets were $4 \mathrm{~m}$ long with a mesh size of $2 \times 2 \mathrm{~mm}$ in the first $3 \mathrm{~m}$ and $1 \times 1 \mathrm{~mm}$ in the last $1 \mathrm{~m}$. The mouth of each net had a total area of $0.8 \mathrm{~m}^{2}$ and sampled the hyperbenthos from 20 to 
Table 1. Sampling sites where the peak abundances of Neomysis integer were recorded

\begin{tabular}{|c|c|c|c|c|c|c|c|}
\hline Date & Station & $\begin{array}{l}\text { Salinity } \\
\text { (PSU) }\end{array}$ & $\begin{array}{l}\text { Temp } \\
\left({ }^{\circ} \mathrm{C}\right)\end{array}$ & $\begin{array}{c}\text { Oxygen } \\
(\%)\end{array}$ & $\begin{array}{l}\text { Secchi } \\
(\mathrm{cm})\end{array}$ & $\mathrm{pH}$ & $\begin{array}{c}\text { Conductivity } \\
\left(\mu \mathrm{S} \mathrm{cm}^{-1}\right)\end{array}$ \\
\hline 27 Nov 1990 & $\mathrm{BA}$ & 17.0 & 8.4 & 65 & 40 & 7.65 & 28.1 \\
\hline 11 Dec 1990 & OV & 17.1 & 6.0 & 75 & 45 & 7.60 & 28.3 \\
\hline $08 \mathrm{Jan} 1991$ & $\mathrm{SA}$ & 9.0 & 5.8 & 79 & 40 & 7.88 & 15.2 \\
\hline $21 \mathrm{Jan} 1991$ & ov & 14.6 & 4.3 & 90 & 45 & 7.85 & 25.2 \\
\hline 05 Feb 1991 & SA & 11.8 & 2.8 & 64 & 25 & 7.63 & 19.8 \\
\hline 22 Feb 1991 & OV & 18.2 & 1.4 & 95 & 40 & 7.88 & 29.9 \\
\hline 05 Mar 1991 & $\mathrm{BA}$ & 12.3 & 4.8 & 67 & 40 & 7.54 & 19.8 \\
\hline 18 Mar 1991 & $\mathrm{SA}$ & 13.3 & 8.2 & 47 & 40 & 7.42 & 21.6 \\
\hline 12 Apr 1991 & $\mathrm{BA}$ & 13.1 & 11.0 & 75 & 60 & 7.64 & 20.8 \\
\hline 24 Apr 1991 & $\mathrm{SA}$ & 18.7 & 9.7 & 98 & 100 & 7.86 & 26.5 \\
\hline 08 May 1991 & $\mathrm{LI}$ & - & - & - & - & - & - \\
\hline 11 Jun 1991 & $\mathrm{BA}$ & 15.0 & 15.3 & 88 & 55 & 7.88 & 24.3 \\
\hline 26 Jun 1991 & $\mathrm{BA}$ & 14.4 & 16.8 & - & 45 & 7.68 & 23.5 \\
\hline 09 Jul 1991 & SA & 11.7 & - & - & 70 & 7.42 & 16.1 \\
\hline 24 Jul 1991 & ov & 17.5 & 19.6 & 84 & 50 & 7.61 & 28.8 \\
\hline 12 Aug 1991 & LI & 10.3 & 22.8 & 49 & 50 & 7.45 & 17.6 \\
\hline 20 Aug 1991 & SA & 18.6 & 20.5 & 110 & 100 & 7.22 & 30.6 \\
\hline 19 Sep 1991 & OV & 18.9 & 21.5 & 103 & 125 & 7.84 & 34.9 \\
\hline 07 Oct 1991 & $\mathrm{BA}$ & 16.8 & 16.3 & 83 & 45 & 7.68 & 28.0 \\
\hline 17 Oct 1991 & $\mathrm{SA}$ & 21.4 & 14.8 & 106 & 80 & 7.85 & 35.1 \\
\hline 05 Nov 1991 & $\mathrm{BA}$ & 17.7 & 11.4 & 86 & 50 & 7.81 & 29.5 \\
\hline 18 Nov 1991 & $B A$ & 13.3 & 9.1 & 70 & 50 & 7.70 & 22.1 \\
\hline $03 \mathrm{Dec} 1991$ & $\mathrm{SA}$ & 12.6 & 7.3 & 44 & 45 & 7.41 & 21.4 \\
\hline $16 \operatorname{Dec} 1991$ & $\mathrm{SA}$ & 17.3 & 4.0 & 73 & 55 & 7.67 & 28.9 \\
\hline Average & & 15.2 & & 79 & 56 & 7.66 & 25.0 \\
\hline $\mathrm{SD}$ & & 3.1 & & 18 & 23 & 0.18 & 5.4 \\
\hline
\end{tabular}

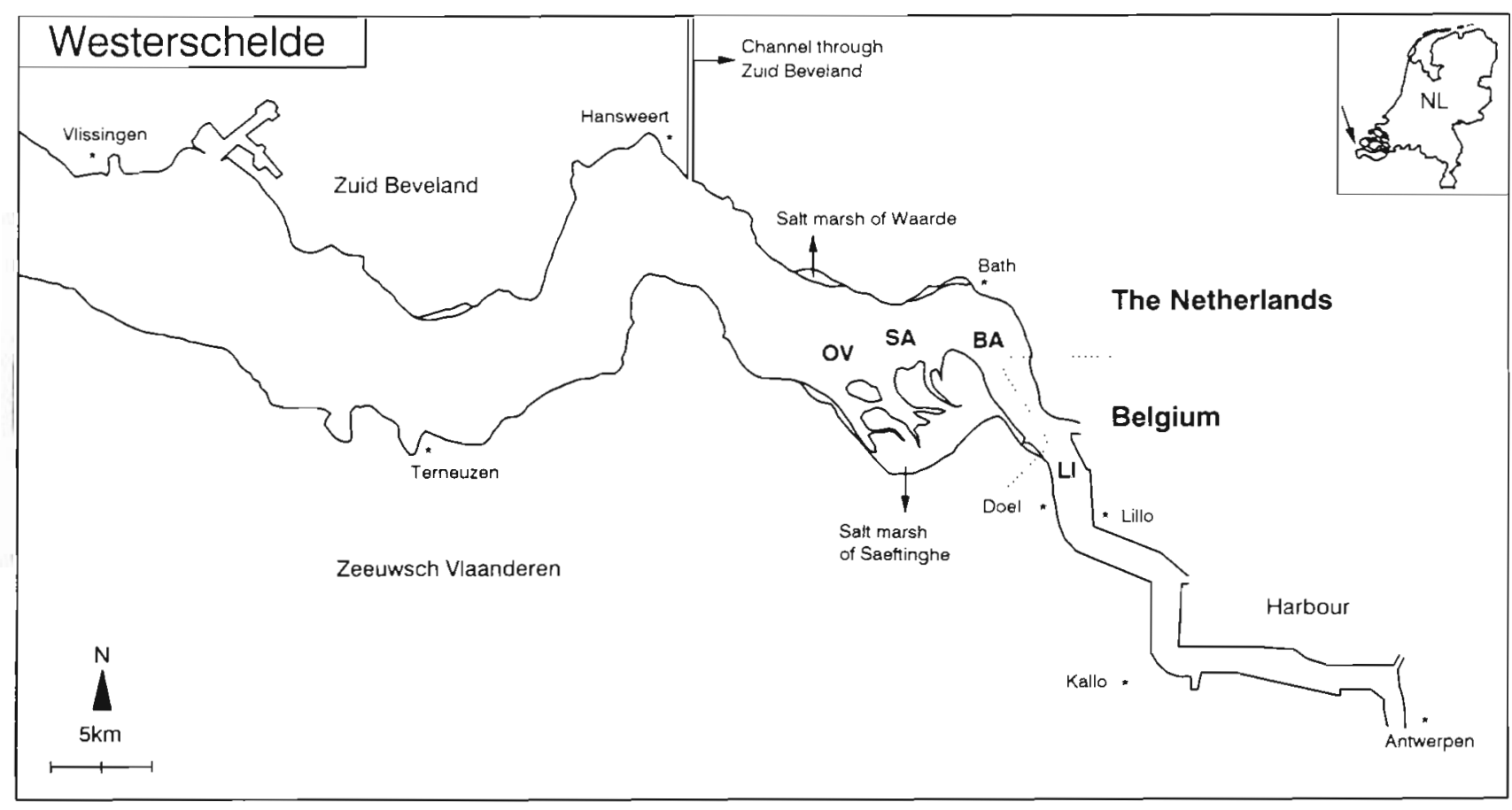

Fig. 1. Study area and the 4 sampling sites, Westerschelde estuary, SW Netherlands 
$100 \mathrm{~cm}$ above the bottom. The sledge was towed for $1000 \mathrm{~m}$ at an average ship speed of $4.5 \mathrm{knots}$ relative to the bottom. Positioning was done by radar readings from fixed points. The total area sampled on each occasion was thus approximately $1000 \mathrm{~m}^{2}$. Trawling was always done with the tide. The samples were taken in the main ebb-tidal channel of the estuary (where possible, the $10 \mathrm{~m}$ depth isobath was followed). The samples were immediately preserved in a buffered formaldehyde solution, $7 \%$ final concentration. Salinity, conductivity, $\mathrm{pH}$, dissolved oxygen concentration, temperature (all measured at $1 \mathrm{~m}$ above the bottom) and Secchi disc depth were recorded at the end of each haul (Table 1).

Laboratory procedures. Samples were sorted and the number of specimens per sample was counted. Each sampling date, the sample with the highest number was selected for further analysis (Table 1). After picking out all Neomysis integer specimens in each catch these were emptied on a white tray divided into 48 squares. Subsamples, each containing 500 specimens, were then obtained by picking from randomly selected squares. About 1000 individuals of $N$. integer were thus obtained for each sample (500 from the upper net and 500 from the lower net). These were sexed and categorized in 6 life cycle stages according to Mauchline (1980): adult males, adult females, subadult males, subadult females, juveniles and gravid females. Mauchline's 7 th stage, post-gravid females, was not distinguished in this study. Adult males are distinguished by their elongated 4 th pleopods which reach beyond the posterior edge of the last abdominal segment. They are further characterised by a welldeveloped and setose lobus masculinus between the flagellae of the antennal peduncle. Adult females all have a fully developed marsupium between their thoracic legs. Juveniles lack secondary sexual characteristics. A further distinction between adult and subadult (immature) males and females is often more subjective. For subadult males the following criteria were used: the 4 th pleopods stop short of reaching the end of the last abdominal segment and/or the lobus masculinus is present but it is much smaller than in adult males and it is not yet setose. The latter criterion is the most reliable one to distinguish the immature males from the juveniles. Females were categorized as adults when their marsupia were large enough to be seen from the lateral side. In contrast the oostegites between the thoracopods in subadult females are only visible when the ventral side of the animal is carefully examined. Adult females were further divided into females without larvae (fully developed but empty marsupia) and 'gravid' or ovigerous females (larvae present in the marsupium). When such gravid females were present, larval counts were made on 60 females with complete broods per sample. Bisexual individuals, i.e. individuals which have elongated 4th pleopods and a marsupium, were rare (less than 30 individuals encountered in the study) and were excluded from further analyses.

In each sample, the standard lengths (the distance from the base of the eye stalk to the end of the last abdominal segment) of 60 individuals of Neomysis integer per sex and per developmental stage were measured to the nearest $0.1 \mathrm{~mm}$ using a calibrated binocular microscope with drawing mirror and a digitizer (subsamples taken in a similar way as described above).

Fifty specimens (10 individuals from each stage and sex, excluding gravid females) from the April and October samples were used for weight measurements. Specimens covering the entire representative size range for each stage were selected for this analysis. They were dried in an oven at $60^{\circ} \mathrm{C}$ for $5 \mathrm{~d}$. The dry weight of the mysids was determined to the nearest microgram. The ash weight of the individuals was later measured after inceneration at $550^{\circ} \mathrm{C}$ for $2 \mathrm{~h}$. The ash-free dry weight (AFDW) of the mysids was then calculated as the difference between the dry weight and ash weight. Length-weight regressions were linearised through double logarithmic transformation. Possible differences between spring and autumn individuals were assessed by analysis of covariance of the corresponding linear regressions. The same 100 specimens were also used to determine regressions between standard length (SL) and 2 other length measures frequently used in mysid research: carapace length $(\mathrm{CL}$, the distance from the tip of the rostrum to the mediodorsal margin of the carapace) and total length ( $\mathrm{TL}$, the distance from the base of the eye stalk to the posterior end of the uropods excluding the setae).

Data analysis. Density of the population is expressed as number of individuals ( $\mathrm{n}$ ) per $\mathrm{m}^{2}$, biomass as $\mathrm{mg}$ AFDW per $\mathrm{m}^{2}$.

On each sampling date the mysids were pooled in $1 \mathrm{~mm}$ length classes. Because preliminary examination of the data revealed length and growth differences between males and females, length-frequency data of the 2 sexes were analysed separately unless otherwise stated. Juveniles were divided equally over the male and female data matrices. To facilitate calculations of biomass, a regression between SL and AFDW was determined by the least-squares method. Biomass was then derived from the length-frequency distributions and the SL-AFDW regression.

In order to detect and separate cohorts the lengthfrequency distributions were analyzed with the Bhattacharya method (Bhattacharya 1967, implemented in Pauly \& Caddy 1985). It splits composite length- 
frequency distributions into separate normal distributions (Sparre 1985). The means of the normal distributions for all sampling dates are then linked to trace the modal length progression of the cohorts.

After cohort separation, the resulting mean sizes by age for each cohort and sex were submitted to ELEFAN I (Pauly \& David 1981) in order to determine cohort and sex specific growth curve parameters.

The growth model used in ELEFAN I is a seasonally oscillating version of the generalized von Bertalanffy growth function (Gayanilo et al. 1989):

$$
L_{t}=L_{\infty}\left(1-\mathrm{e}^{\left.\left[-K\left(t-t_{0}\right)-\frac{C K}{2 \pi}\left[\sin 2 \pi \mid t-t_{s}\right)-\sin 2 \pi \mid t_{0}-t_{s}\right)\right]}\right)
$$

where $L_{t}$ is the predicted standard length at age $t_{1} L_{s}$ is the asymptotic length, $K$ is a growth constant, $C$ is the amplitude of the seasonal growth oscillation, $t_{\mathrm{s}}$ is the starting point of that oscillation with respect to $t_{0}$ [within ELEFAN $t_{\mathrm{s}}$ is replaced by the winter point WP corresponding to the time of the year with the slowest growth (WP $\left.=t_{\mathrm{s}}+0.5\right)$ ], and $t_{0}$ is the age at zero length. A detailed explanation of the different parameters is given in Pauly (1987).

An independent estimate of $L_{\infty}$ was obtained with the Wetherall method as modified by Pauly (1986) (also available in the ELEFAN package).

Production estimates of Neomysis integer were obtained from the basic length-frequency data, and the length-weight regression. The first 2 sampling dates (27 November and 12 December 1990) were not used in the calculations. The year over which production was calculated thus started on 8 January and ended on 16 December 1991.

Three commonly used methods were applied to estimate annual production: the growth summation method, the removal summation method, and the sizefrequency method (Waters 1977, Menzie 1980, Crisp 1984).

In the growth summation method (Crisp 1984) production $(P)$ is calculated as the increment of biomass from one sampling time to the next throughout the cohort's life span. In mathematical terms this can be expressed as:

$$
P=\sum N \Delta \bar{W}
$$

where $N=$ the number of individuals at time $t$, and $\Delta \bar{W}=$ the increase in weight of an average individual during the time interval.

The removal summation method (Crisp 1984) sums the loss (instead of growth) in weight between consecutive samples for the whole life span of the cohort and is given as:

$$
P=\sum \bar{W} \Delta N
$$

where $\bar{W}$ is the weight of the average individual dur- ing the sampling interval, and $\Delta N$ is the change in number of individuals during the interval.

The size-frequency method used here (Menzie 1980) involves the calculation of an average length-frequency distribution from quantitative samples taken at evenly spaced intervals throughout the year. Production is estimated as the sum of the losses of individuals from one size class to the next and the biomass loss this represents, compensated by the increase in mean individual weight with increasing age. The following expression was used:

$$
P=\left[i \sum_{j=1}^{i}\left(\bar{n}_{j}-\bar{n}_{j+1}\right)\left(W, W_{j+1}\right)^{1 / 2}\right] \times 365 / \mathrm{CPI}
$$

where $P$ is annual production, $i$ is the number of size classes, $\bar{n}_{j}$ is the number of individuals that have developed into a particular size category $j$ during the year, $W_{j}$ is the mean weight of an individual in the $j$ th size category, and CPI is the cohort production interval (the number of days from the date of birth of the cohort to the attainment of the largest size).

The size-frequency method was originally designed to estimate production in mixed populations of univoltine species (Hynes \& Coleman 1968). However, it has usually been applied in single species production studies. In species with life spans different from 1 yr the cohort production is multiplied by the ratio of 365 to the cohort production interval, CPI, in days (365/CPI) to obtain annual production. In the present study the 3 cohorts differed in their life span. Hence an average CPI was calculated from the CPIs of the 3 cohorts. Since the 3 cohorts overlapped in time, the use of this average CPI may not yield a good estimate of production. To check on this another estimate of annual production was obtained by considering each cohort separately. Annual production according to this treatment is then the sum of the production of each of the 3 cohorts. Waters \& Crawford (1973) suggested that separate production estimates are needed in species which show sex-related length differences. As this was clearly the case for Neomysis integer in the study area, production estimates were also made for the males and females separately.

Furthermore, an independent estimate of production was obtained from the mortality rate. Under certain conditions (in case of a steady state model and if individual growth is described by a von Bertalanffy function) the total mortality of a population is equal to the $\mathrm{P} / \mathrm{B}$ ratio of the population (Allen 1971). If the average annual biomass of the population is known, the production can be determined as the product of the biomass and the $P / B$ obtained from the mortality rate. Total mortality $(Z)$ for these calculations was obtained from a length converted catch curve (e.g. Gulland 1983) 


\section{RESULTS}

\section{Location of the abundance maximum and environmental variables}

The density peaks of the Neomysis integer population were always distinctively located in one station. The abundance maxima were usually found at Stns SA and BA (9 and 8 times, respectively). Only twice was the maximum located upstream of the Dutch-Belgian border (at Stn LI) and only 4 times in the most downstream station (OV).

Most environmental variables measured (Table 1) did not display clear seasonal patterns. Salinity varied between 9 and 21.4 PSU with an average of $15.2 \pm 3.12$ (conductivity 15.2 to $35.1 \mu \mathrm{S} \mathrm{cm}-1$, average $25 \pm 5.42 \mu \mathrm{S} \mathrm{cm}^{-1}$ ). Average $\mathrm{pH}$ was $7.66 \pm 0.18$. Dissolved oxygen concentration averaged $78.6 \pm$ $18.3 \%$ of the saturation value and only reached saturation values on 3 occasions, but dropped below $50 \%$ twice. Peaks of $100 \mathrm{~cm}$ Secchi disc depth and more were observed in April and August-September while the annual average was about $60 \mathrm{~cm}$. The temperature in the water column was $8.4^{\circ} \mathrm{C}$ at the start of sampling in November. It decreased to a minimal value of $1.4{ }^{\circ} \mathrm{C}$ in February and then gradually increased to a maximum of $22.8^{\circ} \mathrm{C}$ in August. From September onwards it decreased again to winter values of $4^{\circ} \mathrm{C}$ by the end of sampling in December.

\section{Seasonal changes in density, biomass, length composition and stage distribution}

The allometric relationships between total length (TL), carapace length (CL) and standard length (SL) were found to be:

$$
\begin{aligned}
& \mathrm{TL}=1.165 \mathrm{SL}-0.080 \quad(\mathrm{~N}=112, \mathrm{r}=0.997, \mathrm{p}<0.001) \\
& \mathrm{CL}=0.266 \mathrm{SL}+0.439 \quad(\mathrm{~N}=112, \mathrm{r}=0.908, \mathrm{p}<0.001)
\end{aligned}
$$

The following SL-AFDW regression, significant at the $p<0.001$ level, was used for the calculation of biomass:

$$
\ln (\mathrm{AFDW})=2.267 \ln (\mathrm{SL})-5.539 \quad(\mathrm{~N}=100, \mathrm{r}=0.997)
$$

No significant differences $(p>0.5)$ were found between SL-AFDW regressions of spring and autumn individuals, nor between males and females.

The seasonal pattern in density and biomass is shown in Fig. 2. Mean density for the study period was 28 ind. $\mathrm{m}^{-2}$ with a minimum of 2.5 ind. $\mathrm{m}^{-2}$ in December 1990 and a maximum of 128 ind. $\mathrm{m}^{-2}$ in June. Mean annual biomass was $54 \mathrm{mg}$ AFDW $\mathrm{m}^{-2}$.

In autumn and winter (October to the end of February), densities were low (less than 25 ind. $\mathrm{m}^{-2}$ ). In spring (March, April and May) densities remained low but biomass increased due to growth. From late spring onwards high densities and biomass of Neomysis integer were recorded, with peak densities of more than 100 ind. $\mathrm{m}^{-2}$ in June and August (Fig. 2).

In the observed length-frequency distributions by date several bimodalities (Fig. 3a) indicate recurring

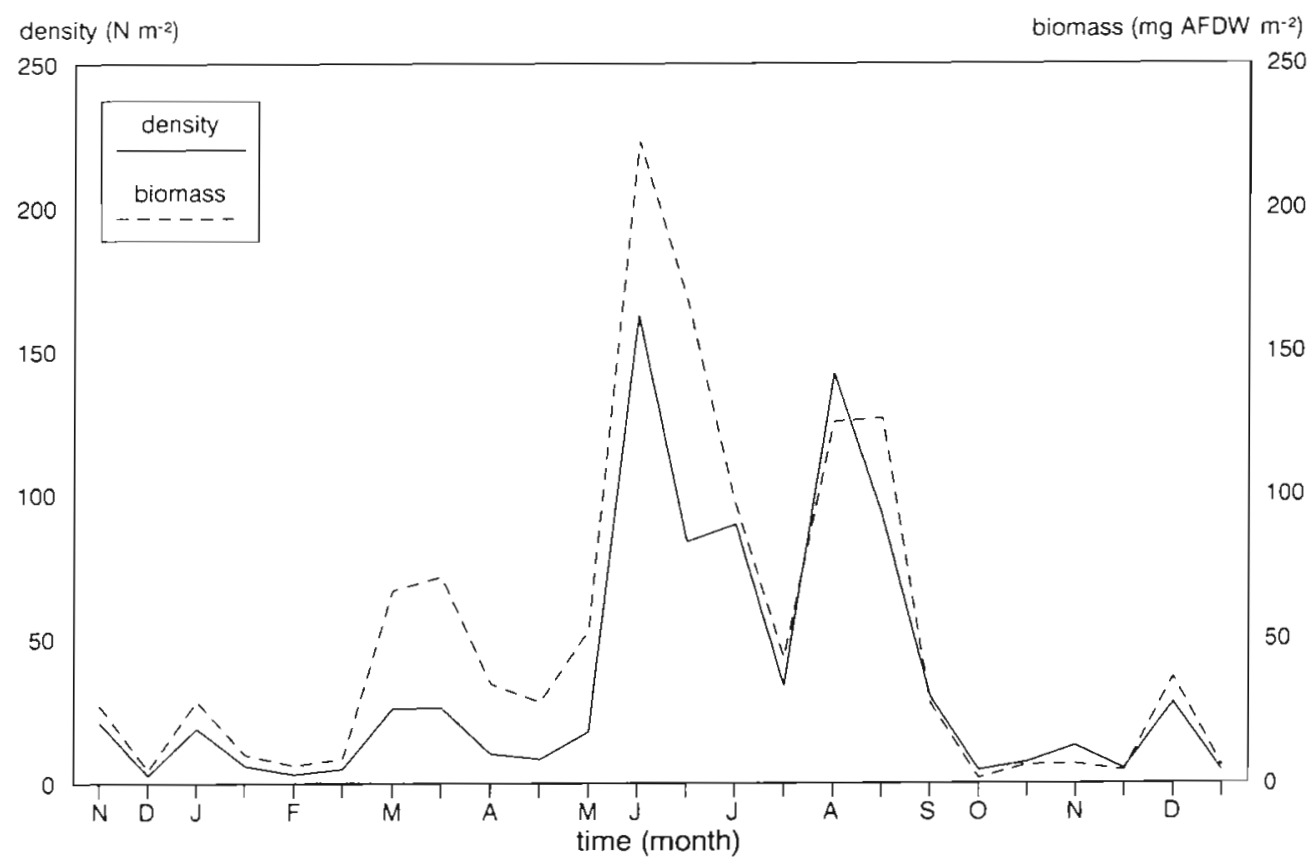

Fig. 2. Neomysis integer. Density and biomass for each sampling date 

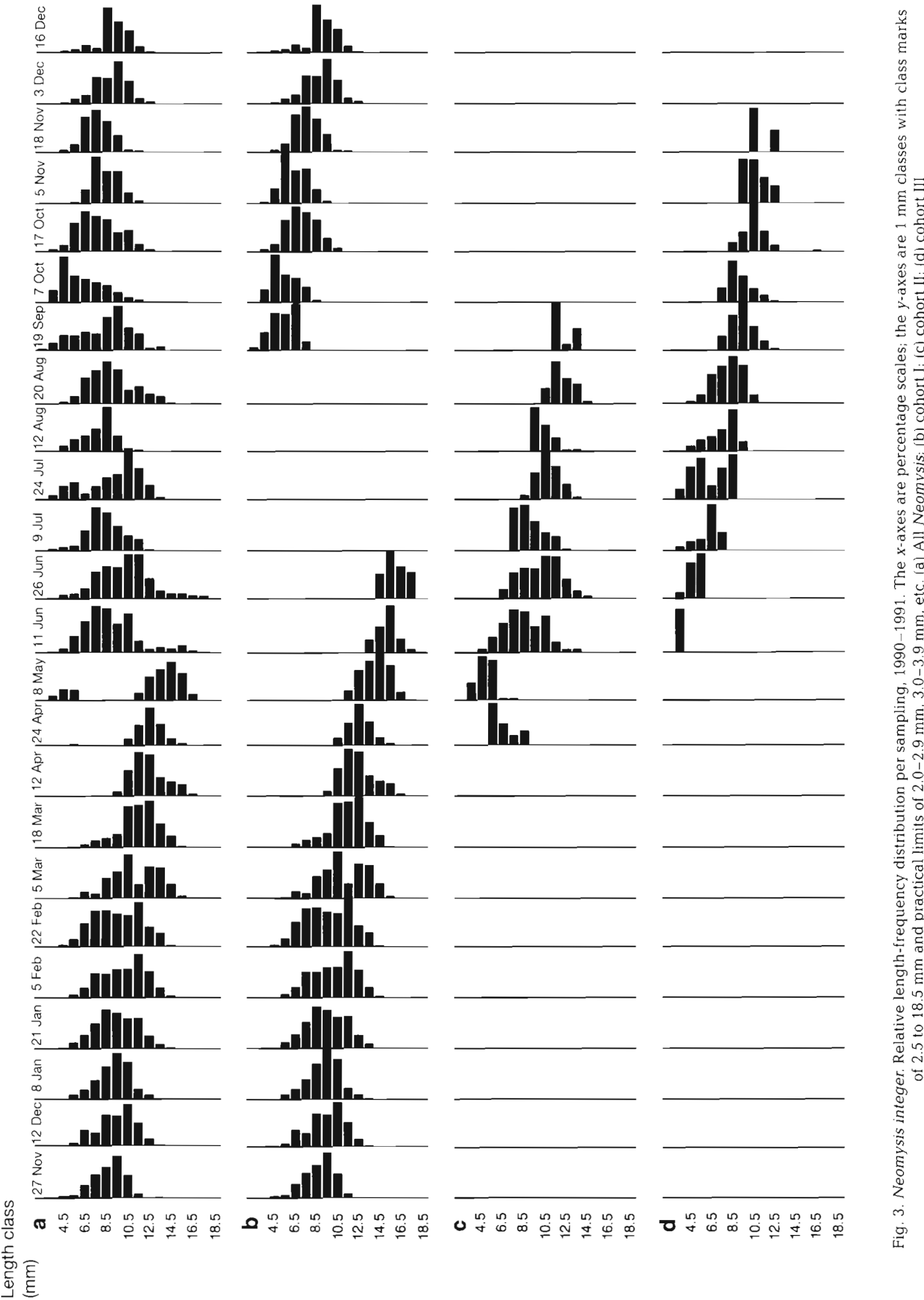

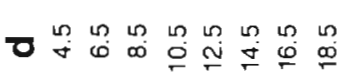

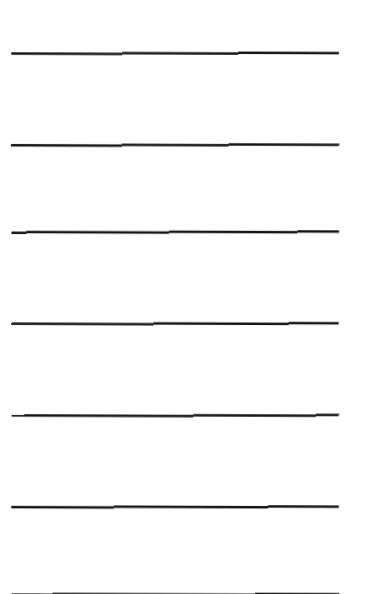




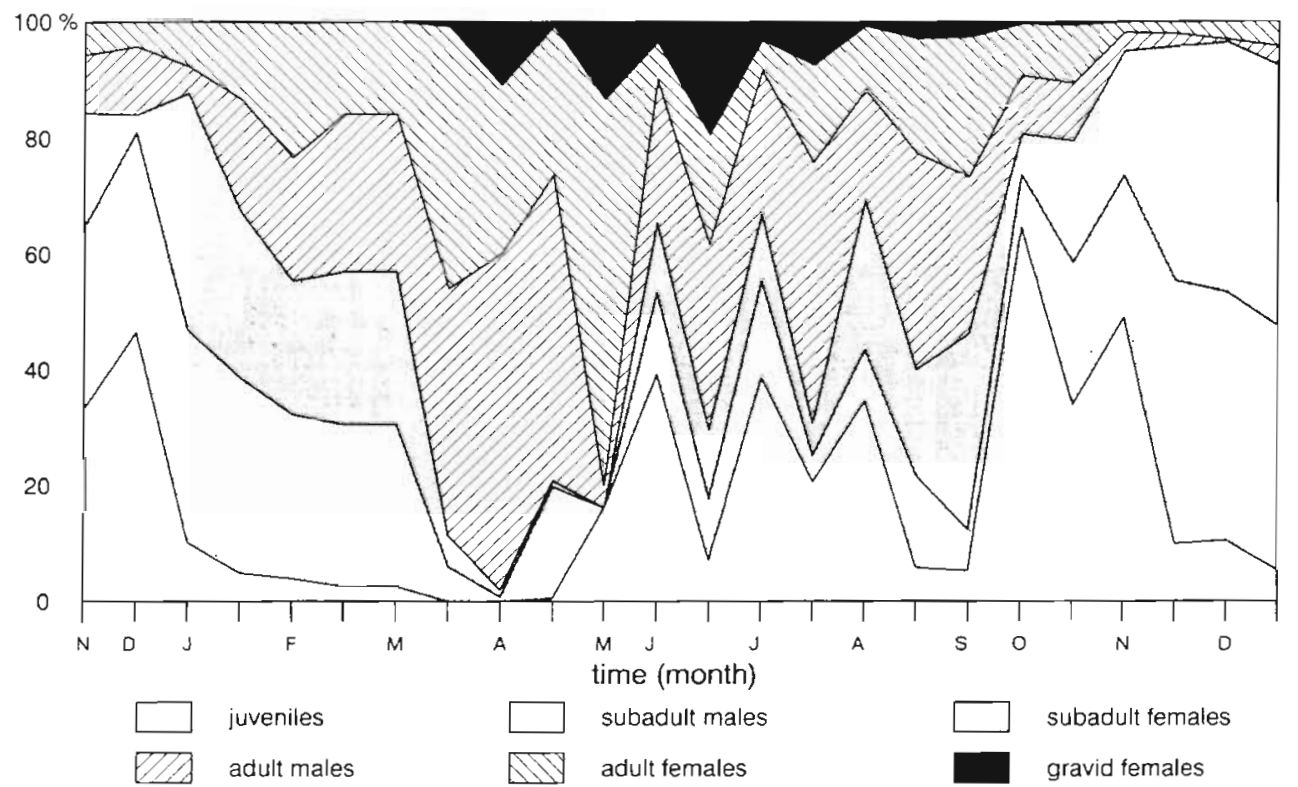

Fig. 4. Neomysis integer. Observed population structure on each sampling date

recruitment of cohorts. The larvae of mysids develop in the marsupium of the females and are released as miniature mysids at a length of about $2 \mathrm{~mm}$ (Mauchline 1980). Recruitment of a spring cohort in AprilMay was obvious as well as the presence of an overwintering generation that grew from November 1990 to May 1991 and from October 1991 through December 1991, respectively. The summer situation was generally more complex. Maximum observed length was $18.7 \mathrm{~mm}$ for a female in June.

The stage composition of the population on each sampling date is presented in Fig. 4. In November and December 1990 , about $40 \%$ of the population were (large) juveniles. Immature males and females together accounted for another $40 \%$ of the population. Less than $20 \%$ of the population were adults. Throughout winter and in early spring juveniles appeared to be growing gradually into subadult stages, and the subadults simultaneously became adult males and females. In early March the number of adults increased sharply and some of the females were gravid. In early April nearly all mysids were adult and a substantial number of gravid females was observed. Throughout late spring and summer changes of the population structure were more difficult to follow. Still, 3 periods of juvenile-subadult recruitment, each preceded by an increase in the percentage of gravid females, were evident: May-June, July-August and SeptemberNovember. Stage composition from November 1991 onwards was similar to the observations in the year before with a dominance of subadults.

\section{Cohort separation}

Three different cohorts were identified in the lengthfrequency distribution. The overwintering cohort (cohort I) was first detectable in November 1990 at a mean length of $8 \mathrm{~mm}$ indicating that these individuals were born before the start of the sampling period. The mean length of this cohort increased to $14 \mathrm{~mm}$ by May-June. This cohort died out by the end of June. A corresponding cohort for the next year was first visible in September 1991 having a mean length of $4 \mathrm{~mm}$. These mysids had attained a mean length of $9 \mathrm{~mm}$ by the end of sampling in December. The spring cohort (cohort II) was detected in late April-May at a mean length of $3 \mathrm{~mm}$. By the end of June cohort II had an average length of about $10 \mathrm{~mm}$. This cohort was not detectable in early August. The summer cohort (cohort III) showed a similar increase in average size from its recruitment in July to the death of the last mysids in the first half of October.

Data on adult length also contributed to a reliable separation of the cohorts. The mean length of the adults of both sexes varied considerably during the course of the year (Fig. 5). Mean length of overwintering adult males increased steadily from about $9 \mathrm{~mm}$ in November to more than $12 \mathrm{~mm}$ in April. The decrease in mean size and the high standard deviations in June, August and November indicate co-occurrence of adult males belonging to different generations. Adult females showed similar patterns of variation in mean length: the average increase in length was from 


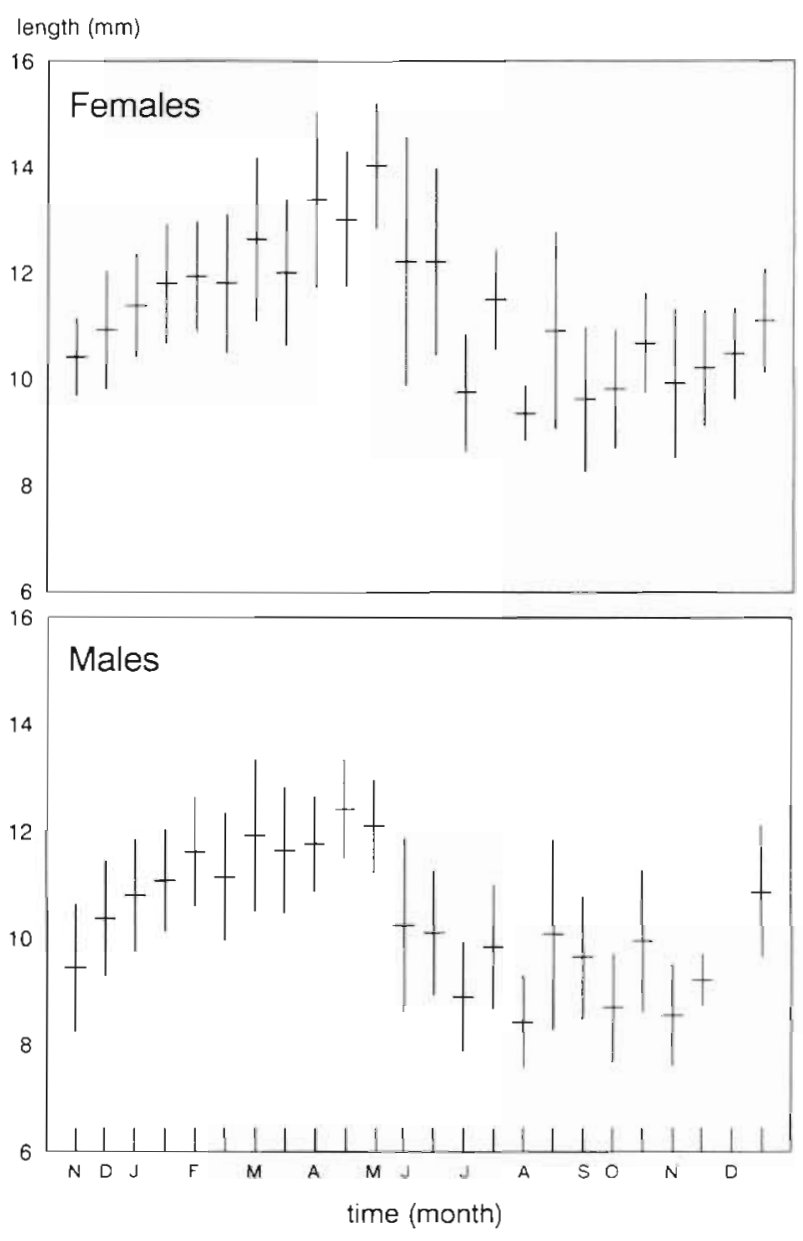

Fig. 5. Neomysis integer. Temporal variation in mean length $( \pm S D)$ of adult males and females

10 to $14 \mathrm{~mm}$. As in case of the males the occasional decrease in mean size and standard deviations indicate co-occurrence of individuals belonging to 2 generations.

Length-frequency distributions and population structure of the 3 cohorts are presented in Figs. 3b, c, d $\& 6$, respectively. The autumn samples contained only recently released individuals from cohort I, the majority of which overwintered as subadults and matured in March. Gravid females were present from April until June. From May onwards cohort I consisted to a very high extent of adult females, suggesting that the males died soon after mating. The cohort I females released the young of cohort II which caused the density peak in early May. Individuals of cohort II matured very rapidly: the first gravid females were already observed in June. The last juveniles were observed in August and breeding continued until the disappearance of the cohort in September. Cohort III juveniles appeared in the June samples and continued to recruit until October. This cohort also matured rapidly and bred from
August until October, yielding the juveniles of the new overwintering generation. The last cohort III individuals died in November. No difference in mortality between the sexes was observed for the summer cohorts.

\section{Growth}

The growth parameters of the von Bertalanfy growth curves of the 3 separate cohorts are presented in Table 2. In Fig. 7 these growth curves are plotted together with the corresponding modal length of the observed length-frequency distributions. Only the overwintering generation showed seasonally oscillating growth $(C>0.5)$. From September through November the mysids grew at a rate of 3 to $4 \mathrm{~mm} \mathrm{mo}^{-1}$. In December growth slowed down and ceased almost completely during the winter months (WP $=t_{\mathrm{s}}-0.5$ $=0$ ). In spring, the mysids regained their fast growth
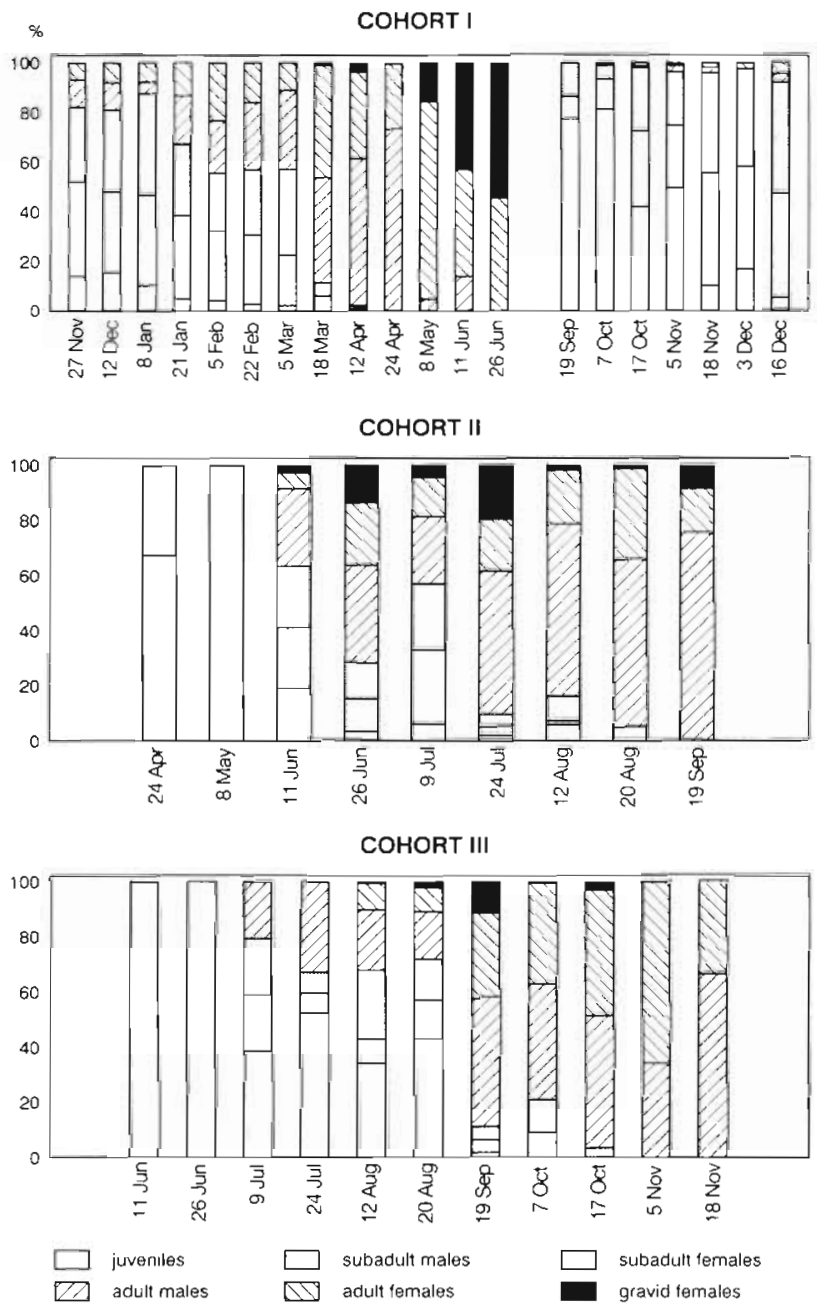

Fig. 6. Neomysis integer. Population structure of the 3 cohorts 
Table 2. Neomysis integer. Growth parameters of the von Bertalanfy growth curves of the 3 cohorts and both sexes separately. $L_{\infty}$ : asymptotic length; K: growth constant; $C$ : amplitude of seasonal growth oscillation; $t_{\mathrm{s}}$ : starting point of oscillation; $t_{0}$ : age at zero length; $\mathrm{Rn}$ : a measure of goodness of fit

\begin{tabular}{|lcccccc|}
\hline Sex/Cohort & $L_{\mathrm{co}}$ & $K$ & $C$ & $t_{\mathrm{s}}$ & $t_{0}$ & $\mathrm{Rn}$ \\
\hline Males I & 16.0 & 2.70 & 0.66 & 0.50 & 0.72 & 0.75 \\
Females I & 19.0 & 3.00 & 0.80 & 0.52 & 0.78 & 0.69 \\
Males II & 14.3 & 3.43 & 0.00 & 0.00 & 0.20 & 0.61 \\
Females II & 16.0 & 3.35 & 0.00 & 0.00 & 0.25 & 0.48 \\
Males III & 13.1 & 3.01 & 0.00 & 0.00 & 0.33 & 0.50 \\
Females III & 14.3 & 3.37 & 0.00 & 0.00 & 0.41 & 0.76 \\
\hline
\end{tabular}

\section{Brood size}

The number of larvae in the marsupium, i.e. the brood size $(b)$, showed a strong positive correlation with female length $(I)$ (Fig. 8):

$$
\text { or } \quad \begin{aligned}
\ln (b) & =-3.349+2.676 \ln (l) \\
\quad b & =0.0365 l^{2.656} \\
& (\mathrm{n}=420, \mathrm{r}=0.866, \mathrm{p}<0.001)
\end{aligned}
$$

Analysis of covariance showed that females in the overwintering generation had significantly larger broods than females in the spring and summer generations $(p<0.05)$. The difference in brood

rate. There was no seasonal oscillation detected in the growth of the mysids of the spring and summer generations $(C=0)$. In these cohorts the smaller mysids (mainly juveniles and subadults) grew fastest (3 to $4 \mathrm{~mm} \mathrm{mo}^{-1}$ ); the larger mysids (mainly adults) grew less ( 1 to $2 \mathrm{~mm} \mathrm{mo}^{-1}$ ).

Individuals of the overwintering generation attained a larger size than spring or summer individuals (higher $L_{\infty}$ for both sexes). Marked differences in growth patterns of the 2 sexes were evident in all cohorts: the females always had a higher $L_{\infty}$ than the males. The average size at maturity for females $(14 \mathrm{~mm})$ and males $(10 \mathrm{~mm})$ of the overwintering generation was larger than for the spring and summer generations at $10 \mathrm{~mm}$ (females) and less than $9.5 \mathrm{~mm}$ (males). size between the spring and,summer generations was marginally significant at $p=0.067$. The following equations were found to apply to the 3 cohorts:

$$
\begin{array}{ll}
\text { Cohort I } & \ln (b)=-3.720+2.828 \ln (l) \\
& (\mathrm{n}=167, \mathrm{r}=0.655, \mathrm{p}<0.01) \\
\text { Cohort II } & \ln (b)=-2.307+2.223 \ln (l) \\
& (\mathrm{n}=149, \mathrm{r}=0.562, \mathrm{p}<0.01) \\
\text { Cohort III } & \ln (b)=-0.974+1.673 \ln (l) \\
& (\mathrm{n}=104, \mathrm{r}=0.615, \mathrm{p}<0.01
\end{array}
$$

Thus, at the same body size, a female of the overwintering generation on average produces a higher number of larvae per brood than a female of the spring or summer generations.

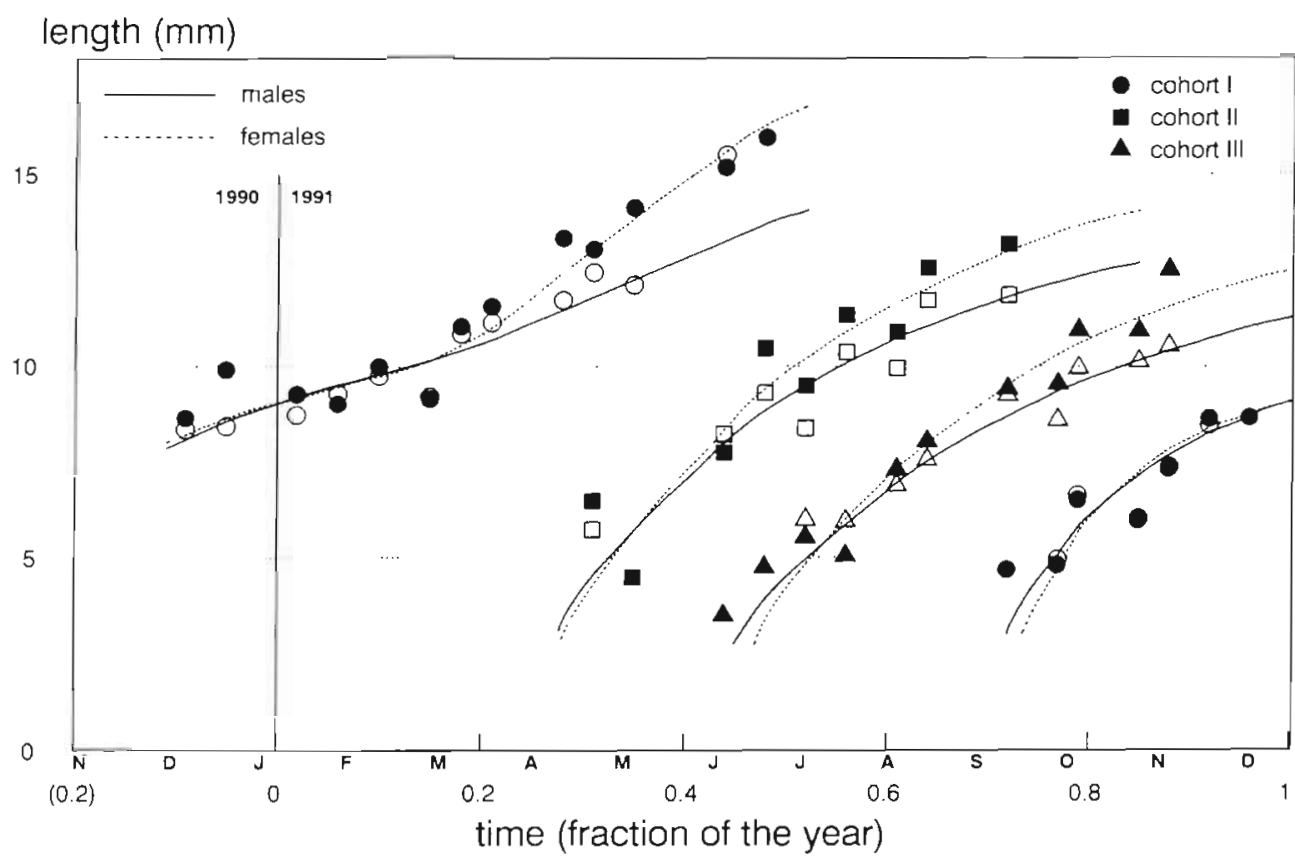

Fig. 7. Neomysis integer. Growth curves of the 3 cohorts and both sexes separately. Open symbols: males; solid symbols: females 
number of larvae per brood

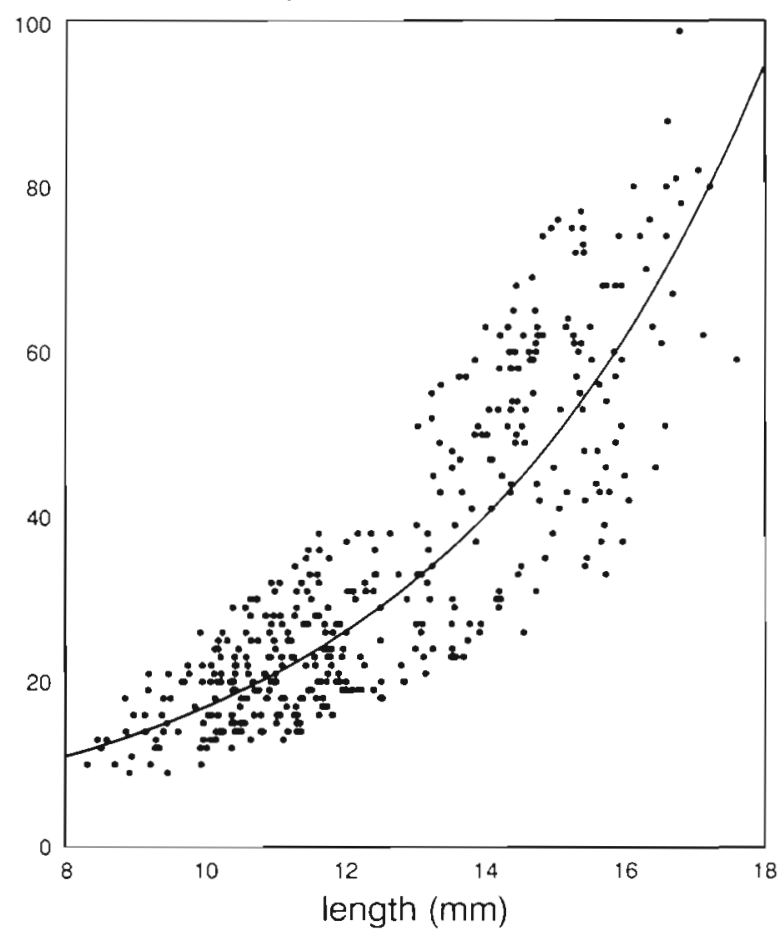

Fig. 8. Neomysis integer. Relation between female length and brood size (all data)

Table 3. Neomysis integer. Summary of the production estimates (mg AFDW $\mathrm{m}^{-2} \mathrm{yr}^{-1}$ ) obtained with different methods

\begin{tabular}{|crcc|}
\hline & Production & Biomass & P/B ratio \\
\cline { 4 - 4 } Growth summation & & & \\
Cohort I & 81.65 & 24.20 & 3.4 \\
Cohort II & 164.51 & 51.28 & 3.2 \\
Cohort III & 76.54 & 19.48 & 3.9 \\
Total & 322.69 & 94.97 & 6.0 \\
Removal summation & & & \\
Cohort I & 81.82 & 24.20 & 3.4 \\
Cohort II & 163.82 & 51.28 & 3.2 \\
Cohort III & 76.78 & 19.48 & 3.9 \\
Total & 322.43 & 94.97 & 6.0 \\
Size-frequency & & & \\
Sexes separated & & & \\
Cohort I & 91.70 & 25.34 & 3.6 \\
Cohort II & 175.41 & 55.93 & 3.1 \\
Cohort III & 61.95 & 21.15 & 2.9 \\
Total & 329.06 & 102.42 & 6.1 \\
Sexes not separated & & & \\
Cohort I & 96.94 & 25.34 & 3.8 \\
Cohort II & 183.54 & 55.93 & 3.3 \\
Cohort III & 65.63 & 21.15 & 3.1 \\
Total & 351.82 & 101.85 & 6.5 \\
All cohorts & 448.52 & 53.73 & 8.3 \\
& & & \\
\hline
\end{tabular}

\section{Production}

The production estimates for Neomysis integer obtained with the different methods and at different levels of pooling of sexes and cohorts are summarised in Tables $3 \& 4$. The annual production estimates obtained with the growth summation and removal summation methods are almost identical $1322 \mathrm{mg}$ AFDW $\mathrm{m}^{-2} \mathrm{yr}^{-1}$ ). The result of the size-frequency method is very close ( $2 \%$ difference) to that of the 2 former methods only when the calculations were performed for the 3 cohorts and both sexes separately. Calculations on pooled length-frequency distributions of the 2 sexes per cohort and of the 3 cohorts (average CPI of 202 d) gave estimates that were $9 \%$ and $39 \%$ higher, respectively. Annual production as estimated from the mortality rate of each cohort was $24 \%$ higher than the estimates using the growth summation, the removal summation or the maximally disaggregated size-frequency methods. Only the values for the first cohort are comparable to the ones obtained with the other methods.

\section{DISCUSSION}

A more or less standard method is presented for studying the life history and population dynamics of mysids from field data. It was successfully applied to the Westerschelde population: samples were taken at regular intervals and the temporal evolution of the population structure was assessed by dividing the animals in a number of distinct sexual and developmental stages (Mauchline 1980). Length-frequency distribu-

Table 4. Neomysis integer. Production estimates $(P$, in $\mathrm{mg}$ AFDW $\mathrm{m}^{-2} \mathrm{yr}^{-1}$ ) obtained from the mortality rate $(Z)$ as compared to the estimates from the disaggregated size-frequency method (s-f)

\begin{tabular}{|c|c|c|c|c|}
\hline & $Z$ & Biomass & $P(Z)$ & $P(\mathrm{~s}-\mathrm{f})$ \\
\hline \multicolumn{5}{|l|}{ Cohort I } \\
\hline Males & 3.15 & 10.10 & 31.82 & 35.65 \\
\hline Females & 4.27 & 15.24 & 65.07 & 56.05 \\
\hline Total & & 25.34 & 96.89 & 91.70 \\
\hline \multicolumn{5}{|l|}{ Cohort II } \\
\hline Males & 3.27 & 29.37 & 96.04 & 91.31 \\
\hline Females & 4.41 & 26.56 & 117.13 & 84.09 \\
\hline Total & & 55.93 & 213.17 & 175.41 \\
\hline \multicolumn{5}{|l|}{ Cohort III } \\
\hline Males & 4.49 & 10.37 & 46.56 & 29.49 \\
\hline Females & 3.90 & 10.78 & 42.04 & 32.46 \\
\hline Total & & 21.16 & 88.60 & 61.95 \\
\hline \multicolumn{2}{|c|}{ Annual production } & & 398.66 & 329.06 \\
\hline
\end{tabular}


tions per stage and per sampling date then allowed an estimate of the number of generations produced in a year. Seasonally oscillating (for the overwintering generation) or generalised (for the spring and summer generations) von Bertalanffy growth models could be fitted to the data, provided males and females were treated separately.

\section{Distribution}

Salinity zones in the Westerschelde are relatively stable (Heip 1988). In the Westerschelde, in contrast to other European estuaries, the Neomysis integer population is concentrated in a narrow zone of approximately $20 \mathrm{~km}$ throughout the year (Mees et al. 1993b). This is attributed to the adverse oxygen conditions upstream of the Dutch-Belgian border (Mees et al. 1993a). The maximum population density is found around the isohaline of 15 and is therefore found at a much higher salinity than in other, less polluted, estuaries. In the Gironde, the Eems (The Netherlands), the Elbe (Germany) and the Shannon (Ireland), for example, the population maximum was found at 3.5 and typically a differential distribution of the developmental stages and sexes along the salinity gradient is observed (Sorbe 1981, Hough \& Naylor 1992). The restricted distribution of the species in the Westerschelde results in a homogenous mix of developmental stages. This facilitates the study of $N$. integer population dynamics and justifies the selection of a single $1000 \mathrm{~m}$ sample in the zone of maximal abundance for the production estimates.

\section{Reproduction}

The life cycle of Neomysis integer in the Westerschelde is similar to the life cycle previously described for this species occurring in other localities. Vorstman (1951), Mauchline (1971), Borghouts (1978), Parker \& West (1979) and Bremer \& Vijverberg (1982) all concluded that $N$. integer produced 3 generations per year in the IJsselmeer (former Zuiderzee), the west coast lochs of Scotland, Lake Veere (southwest Netherlands), in the Frisian lakes (north Netherlands) and in a lough in western Ireland, respectively. Two generations per year were found in the Ythan (Astthorsson \& Ralph 1984) and Eider-Ring estuaries (Kinne 1955) and in the coastal waters in the Baltic Sea (Kinne 1955, Wiktor 1961, Jansen et al. 1980, Rudstam et al. 1986). At lower latitudes life cycles are more complex, breeding being almost continuous throughout the year (Sorbe 1981).

In the Westerschelde, reproduction of Neomysis integer halted completely in winter. It restarted in April when the water temperature rose to $10^{\circ} \mathrm{C}$ and stopped again in October when the temperature dropped below the same value. Females of the overwintering generation had larger brood sizes for mysids of the same length than females in the other generations. Whether this was correlated with a higher fecundity can not be derived from the field data. Smaller brood sizes may be compensated by the production of several broods per female in the spring and summer generations. Indeed, in culture experiments conducted at $20^{\circ} \mathrm{C}$ individual females were found to produce up to 5 consecutive broods (C. R. Janssen unpubl.). The physiological background and/or ecological adaptiveness of these different reproductive strategies remain unclear.

\section{Brood size}

The results of the present study seem to corroborate the hypothesis of Bremer \& Vijverberg (1982) that brood size is positively correlated with salinity: the Westerschelde population lives at a higher salinity than other studied populations and is characterised by the largest average brood sizes reported to date. However, the reason for this and why most populations of Neomysis integer are found at salinity ranges that result in relatively small brood sizes remains unclear. Possible explanations may include a trade-off for suboptimal brood sizes with competitive advantages of living in low-salinity waters which in estuaries coincides with the zone of maximum turbidity: lower (visual) predation pressure, more available food, less competition with other mysids (e.g. Mesopodopsis slabben) or benthic filter feeders.

\section{Growth}

The most frequently used method for determining growth in crustaceans involves the identification and tracing of modes (cohorts which are generated by seasonal reproduction) in the length-frequency distributions. As a result of the asynchrony of moulting between individual mysids the lengths within a cohort are assumed to be normally distributed. Growth curves are then fitted to the mean lengths of the traced cohorts in relation to their age. For the analysis of growth the complete ELEFAN program package (Pauly \& David 1981) proved to be very useful. The Bhattacharya method is a powerful tool for identifying cohorts, but a careful examination of the population structure and length-frequency distributions of the different developmental stages was still necessary. The growth model used was a von Bertalanffy equation which incorporates seasonal variation in growth. In the 
absence of seasonal growth variations this function is reduced to the generalized von Bertalanffy growth equation. We were able to show that differences in growth between the sexual stages had to be taken into account. Seasonally oscillating von Bertalanffy growth equations have previously only been applied to the mesopelagic mysids Meterythrops microphthalma from the Japan Sea (Ikeda 1992) and the hyperbenthic Antarctomysis maxima and Mysidetes posthon from Antarctic waters (Siegel \& Mühlenhardt-Siegel 1988).

\section{Production}

Production estimates of Neomysis integer are difficult to make because of sampling methodological problems. No correction was made for net efficiency which is unlikely to be $100 \%$ as mysids are known to avoid nets to a considerable extent (Mauchline 1980). The abundance of the smallest size classes was certainly underestimated due to mesh selection. Only the water column between $0.2 \mathrm{~m}$ and $1 \mathrm{~m}$ above the bottom was sampled and, though there are indications that a large part of the population is concentrated in this zone throughout the day, some $N$. integer can be found in zooplankton samples taken at intermediate depths. Moreover, only the subtidal channel was sampled and $N$. integer makes extensive use of the salt marshes (Mees et al. 1993a) and possibly of other shallow areas. Samples were preserved for at least 4 mo prior to analysis and the weight loss associated with formalin preservation, estimated to be about $10 \%$ by Bremer \& Vijverberg (1982), was not taken into account. Nor was a correction made for the underestimate of weight which results from backtransformation of the linearised length-weight relationship (Baskerville 1972). Organic matter is also lost during moulting. Holmquist (1959) found that Mysis relicta lost 5 to $10 \%$ of its dry weight due to ecdysis. This bias is not necessarily relevant since use of this refractory chitinous material in the food web is probably limited. Finally no attempt was made to include intra-marsupial production in the calculations. Against this background, the production estimates presented in this study are likely to be too low.

Neomysis integer produced about $0.3 \mathrm{~g} \mathrm{AFDW} \mathrm{m}^{-2}$ $\mathrm{Yr}^{-1}$. This is much higher than the estimate by Bremer \& Vijverberg (1982) for a lacustrine population (10 mg DW m $\mathrm{m}^{-2} \mathrm{yr}^{-1}$ with a P/B of 4.0). However, our estimate is remarkably close to the production values reported for $N$. mercedis in lakes that support similar population densities (summarised in Cooper et al. 1992).

The growth summation and removal summation methods yielded approximately the same production estimates. The use of the size-frequency method is only recommended for populations that can easily be disaggregated into cohorts and/or sexes with more uniform life-history characteristics. Pooling of data leads to an overestimation of production. Indeed, one of the basic assumptions of the size-frequency method is that all species or, as in the case of this study, all sexes and cohorts must have the capability of growing to the same maximum size (Hamilton 1969). Waters \& Crawford (1973) already noted that the method yielded estimates 15 to $26 \%$ higher than the removal summation method and postulated that this could be due to the size difference between the sexes. Although identification of cohorts is not required to obtain a production value with the size-frequency method, not doing so will thus lead to overestimates. The same conclusions apply to the method which uses the total mortality within the population to estimate production. Though not frequently used, the effort required to calculate production with this method is very low, as no abundance and mean individual weight per sampling date is necessary. Only a length-frequency distribution at each sampling date and an estimate of mean annual biomass is required (Brey 1986).

\section{CONCLUSIONS}

The Neomysis integer population of the Westerschelde produced 3 generations per year. The overwintering generation lived from autumn until spring of the following year. The spring generation was born in April and lived for around $3 \mathrm{mo}$, while the summer generation lived from July until early winter of the same year. The spring generation produced the highest number of mysids and accounted for almost half of the annual biomass. The overwintering generation contributed least to the biomass. The biology of the mysids in the latter generation was markedly different from that of individuals belonging to the spring and summer generations: they had a lower growth rate, larger size at maturity and a larger brood size. Within any one cohort both sexes showed different growth characteristics, with the females generally living longer, growing faster and attaining a larger size than the males. Biomass production of Neomysis integer was found to be quite high in the brackish zone of the Westerschelde. The 3 methods for estimating secondary production yielded comparable results. Annual production amounted to $0.3 \mathrm{~g}$ AFDW m $\mathrm{m}^{-2} \mathrm{yr}^{-1}$. The size-frequency method only resulted in values similar to those obtained with the growth summation and removal summation methods when it was applied to the 3 cohorts and both sexes separately. The spring cohort produced nearly half of the total annual production. In spite of its longer lifespan, the overwintering cohort accounted for barely half of the total annual production. 
Acknowledgements. This research was supported by the European Community (contract no. MAST-CT90-0024) as part of the JEEP-92 project. We acknowledge Dr Peter Herman for checking on the methodology and calculations of production. We thank Wim Röber, Piet De Koeyer and Co Van Sprundel, crew of the RV 'Luctor', for their help during sampling. This is contribution No. 716 of the Centre for Estuarine and Coastal Ecology

\section{LITERATURE CITED}

Allen, K. R. (1971). Relation between production and biomass. J. Fish. Res. Bd Can. 28: 1573-1581

Astthorsson, O. S., Ralph, R. (1984). Growth and moulting of Neomysis integer (Crustacea: Mysidacea). Mar. Biol. 79: $55-61$

Baskerville, G. L. (1972). Use of logarithmic regression in the estimation of plant biomass. Can. J. Forest Res. 2: 49-53

Beattie, D. M., de Kruijf, H. (1978). Population dynamics and biomass production of Neomysis integer (Leach) in the Bergumermeer. Verh. int. Verein Limnol. 20: 2566-2571

Bhattacharya, C. G. (1967). A simple method of resolution of a distribution into Gaussian components. Biometrics 23: $115-135$

Borghouts, C. H. (1978). Population structure and life-cycle of Neomysis integer (Leach) (Crustacea, Mysidacea) in two types of inland waters. Verh. int. Verein Limnol. 20: $2561-2565$

Bremer, P., Vijverberg, J. (1982). Production, population biology and diet of Neomysis integer (Leach) in a shallow Frisian lake (The Netherlands). Hydrobiologia 93: 41-51

Brey, T. (1986). Estimation of annual P/B-ratio and production of marine benthic invertebrates from length-frequency data. Ophelia (suppl.) 4: 45-54

Cooper, K. L., Hyatt, K. M., Rankin, D. P. (1992). Life history and production of Neomysis mercedis in two British Columbia coastal lakes. Hydrobiologia 230: 9-30

Crisp, D. J. (1984). Energy flow measurements. In: Holme, N. A., McIntyre, A. D. (eds.) Methods for the study of marine benthos. IPB Handbook No. 16, Blackwell, Oxford p. $284-372$

Gayanilo, F. C., Soriano, M., Pauly, D. (1989). A draft guide to the complete ELEFAN. ICLARM Software 2. International Center for Living Aquatic Resources Management, Manila

Gulland, J. A. (1983). Fish stock assessment. FAO/Wiley series on food and agriculture, Vol. 1. Wiley, Chichester

Hamerlynck, O., Hostens, K., Arrellano, R. V., Mees, J., Van Damme, P. A. (1993). The mobile epibenthic fauna of soft bottoms in the Dutch Delta (SW Netherlands): spatial structure. Neth. J. aquat. Ecol. 27: 343-358

Hamerlynck, O., Mees, J. (1991). Temporal and spatial structure in the hyperbenthic community of a shallow coastal area and its relation to environmental variables. Oceanol. Acta Vol. sp. 11: 205-212

Hamilton, A. L. (1969). On estimating annual production Limnol. Oceanogr. 14:771-782

Heip, C. (1988). Biota and abiotic environment in the Westerschelde estuary. Hydrobiol. Bull. 22: 31-34

Heubach, W. (1969). Neomysis awatschensis in the Sacra. mento-San Joaquin River Estuary. Limnol. Oceanogr. 14 $533-546$

Holmquist, C. (1959). Problems on marine-glacial relicts on account of investigations on the genus Mysis. Berlingska Boktryckeriet, Lund
Hough, A. R., Naylor, E. (1992). Distribution and position maintenance behaviour of the estuarine mysid Neomysis integer. J. mar. biol. Ass. U.K. 72: 869-876

Hynes, H. B., Coleman, M. J. (1968). A simple method of assessing the annual production of stream benthos. Limnol. Oceanogr. 13: 569-573

Ikeda, T. (1992). Growth and life history of the mesopelagic mysid Meterythrops microphthalma in the southern Japan Sea. J. Plankton Res. 14: 1767-1779

Ishikawa, M., Oshima, Y. (1951). On the life history of a mysid crustacean Neomysis integer Nakazawa. Bull. Jap. Soc. scient. Fish. 16: 461-472

Jansen, W., Arndt, E. A., Hahn, W., Bottorf, T. H., Wronnd, F., Raschewski, U. (1980). Untersuchungen zur Populationsentwicklung von Neomysis integer (Leach) in der DarssZingster Boddenkette. Wiss. Z. Wilh.-Pieck-Univ. Rostock 29: $95-97$

Kinne, I. (1955). Neomysis vulgaris Thompson, eine autökologisch-biologische Studie. Biol. Zentralblatt 74: 160-202

Mauchline, J. (1971). The biology of Neomysis integer. J. mar biol. Ass. U.K. 51: 347-354

Mauchline, J. (1980). The biology of mysids and euphausiids Adv. mar. Biol. 18: 1-319

Mees, J., Cattrijsse, A., Hamerlynck, O. (1993a). Distribution and abundance of shallow-water hyperbenthic mysids (Crustacea, Mysidacea) and euphausiids (Crustacea, Euphausiacea) in the Voordelta and the Westerschelde, south-west Netherlands. Cah. Biol. mar. 34: 165-186

Mees, J., Dewicke, A., Hamerlynck, O. (1993b). Seasonal and spatial distribution of hyperbenthic communities along estuarine gradients in the Westerschelde. Neth. J. aquat Ecol. 27: 359-376

Mees, J., Hamerlynck, O. (1992). Spatial community structure of the winter hyperbenthos of the Schelde estuary, the Netherlands, and the adjacent coastal waters. Neth. J. Sea Res. 29: $357-370$

Menzie, C. A. (1980). A note on the Hynes method of estimating secondary production. Limnol. Oceanogr. 25: 770-773

Parker, M., West, B. (1979). The natural history of Neomysis integer (Leach) in Lough Furnace, Co. Mayo, a brackish lough in the West of Ireland. Estuar coast. mar. Sci. 8: $157-167$

Pauly, D. (1986). On improving operation and use of the ELEFAN programs. Part Il. Improving the estimation of $\mathrm{L}_{\infty}$. Fishbyte 4: $18-20$

Pauly, D. (1987). A review of the ELEFAN system for analysis of length-frequency data in fish and invertebrates. In: Pauly, D., Morgan, G. R. (eds.) ICLARM Conf. Proc. 13 International Center for Living Aquatic Resources Management, Manila, p. 7-34

Pauly, D., Caddy, J. (1985). A modification of Bhattacharya's method for the separation of normal distributions. FAO Fish. Circ. 781

Pauly, D., David, N. (1981). ELEFAN I, a BASIC program for the objective extraction of growth parameters from length-frequency data. Meeresforsch. Rep. mar. Res. 28: 205-211

Pezzack, D. S., Corey, S. (1979). The life history and distribution of Neomysis americana (Smith) (Crustacea, Mysidacea) in Passamaquoddy Bay. Can. J. Zool. 57: 785-793

Platenkamp, G. A. J. (1983). Verspreiding, biomassa en groei van epi- en hyperbenthische macrocrustaceeen in het Grevelingen-meer. DIHO student report D6-1983. Delta Institute for Hydrobiological Research, Yerseke

Rudstam, L. G., Hansson, S., Larsson, U. (1986). Abundance, species composition and production of mysid shrimps in a coastal area of the northern Baltic proper. Ophelia (suppl.) 4: $225-238$ 
Siegel, V., Mühlenhardt-Siegel, U. (1988). On the occurrence and biology of some Antarctic Mysidacea (Crustacea). Polar Biol. 8: 181-190

Soetaert, K., van Rijswijk, P. (1993). Spatial and temporal patterns of the zooplankton in the Westerschelde estuary. Mar. Ecol. Prog. Ser. 97: 47-59

Sorbe, J.-C. (1981). La macrofaune vagile de l'estuaire de la Gironde. Distribution et migration des espèces. Modes de réproduction, régimes alimentares. Océanis 6: 579-592

Sparre, P. (1985). Introduction to tropical fish stock assessment. FAO Manual. FAO, Rome

Tattersall, W. M., Tattersall, O. S. (1951). The British Mysidacea. The Ray Society, London, p. 399-409

Tesch, J. J (1911). Bijdragen tot de fauna der zuidelijke Noordzee. VI. Schizopoden, verzameld met de 'Wodan' Jaarb. Rijksinst. Onderz. Zee Helder 1910: 35-83

Toda, H., Takahashi, M., Ichimura, S. (1982). Abundance and life history of Neomysis intermedia Czerniawsky in lake Kasumigaura. Hydrobiologia 93: 31-39

This article was submitted to the editor
Van Eck, G. T M., De Pauw, N., Van Den Langenbergh, M. Verreet, G. (1991). Emissies, gehalten, gedrag en effecten van (micro)verontreinigingen in het stroomgebied van de Schelde en het Schelde-estuarium. Water 60: 164-181

von Oertzen, J. A., Wulf, D., Brügmann, L. (1988). Ecotoxicological effects of two mercury compounds on Neomysis integer (Leach) and Pomatoschistus microps (Kroyer). Kieler Meeresforsch. Sonderh. 6: 414-423

Vorstman, A. G. (1951). A year's investigation on the life cycle of Neomysis vulgaris Thompson. Verh. int. Verein Limnol. 11. $437-445$

Waters, I F. (1977). Secondary production in inland waters. Adv ecol Res. 10: 91-164

Waters, T F., Crawford, G. W. (1973). Annual production of a stream mayfly population: a comparison of methods. Limnol. Oceanogr 18: 286-296

Wiktor, K. (1961). Observations on the biology of Neomysis vulgaris (Thompson) in Zalew Szczecinski (Stettiner Haff) and Zatoka Pomorska (Pomeranian Bay). Przegl. Zool 5: $36-42$

Manuscript first received: July 15, 1993

Revised version accepted: March 25, 1994 